\title{
「健康食品」の安全性·有効性情報による情報提供と最新の話題
}

\author{
千葉剛
}

\section{Information System on the Safety and Effectiveness of Health Foods and Recent Topics}

\author{
Tsuyoshi Chiba \\ Department of Food Function and Labeling, National Institute of Health and Nutrition, National Institutes of \\ Biomedical Innovation, Health and Nutrition; 1-23-1 Toyama, Shinjuku-ku, Tokyo 162-8636, Japan.
}

(Received July 12, 2018)

\begin{abstract}
Along with an increase in self-care and self-medication practices, the use of health foods as primary and secondary methods of disease prevention has increased. Consumers are aware only of the health benefits of dietary ingredients, although the potential risks associated with most ingredients are unknown. Adverse events associated with the use of health foods have been reported, and in some cases they were due to inappropriate use such as the concomitant use of several health foods or health foods and drugs. It is important that healthcare professionals, especially pharmacists, provide reliable, evidence-based information to ensure the safe and appropriate use of dietary supplements by their patients. Thus, we constructed an online database, the "Health Foods Network (HFNet)" that compiles reports on the safety and effectiveness of health foods and their ingredients. It serves to disseminate information based on scientific research not only in Japan but also worldwide. This article provides an overview of the HFNet. Additionally, findings from our recent survey and educational interventions among college students are discussed. We hope that this article will be helpful for pharmacists and other healthcare professionals who provide consultations on the use of health foods.
\end{abstract}

Key words — Health Foods Network (HFNet); health food; education; college student; pharmacist

健康寿命を延ばすためのセルフケア・セルフメ ディケーションが国の政策として打ち出されてい る. セルフケアの一環として「健康食品」の活用が 注目されているが，保健機能食品以外のいわゆる健 康食品には定義がなく，その実態は玉石混交であ る．また，消費者の健康食品に対する認識も十分と は言えず，消費者が適切に利用できる環境が整って いない，健康食品をセルフケアに役立てるには，有 効性だけでなく安全性にも注意しなければならな い，最近では，若い女性におけるプエラリア・ミリ フィカを含有した健康食品の利用による健康被害も 多く報告され，厚生労働省，国民生活センターから 注意喚起が出されている．また，セルフケアが必要 となる高齢者は医薬品を服用している者が多く，相

国立研究開発法人医薬基盤 - 健康 - 栄養研究所国立健 康・栄養研究所食品保健機能研究部（T162-8636 東京 都新宿区戸山 1-23-1)

e-mail: tyschiba@nibiohn.go.jp

本総説は, 日本薬学会第 138 年会シンポジウムS56 で 発表した内容を中心に記述したものである.
互作用は重篤な健康被害につながる可能性もあるこ とから，極めて重要な課題である．医薬品との相互 作用については消費者はもちろん，医師・薬剤師で あってもすべてを明確に判断することは困難である.

そのため健康食品に関する情報提供は重要であ り, 国立研究開発法人医薬基盤・健康・栄養研究所 国立健康・栄養研究所では「健康食品」の安全性・ 有効性情報（Health Foods Network; HFNet）（Fig. 1）サイトを運用し，主に専門職（薬剂師・医師・ 管理栄養士など）を対象として，健康食品に関する 情報提供を行っている.

HFNet の始まりは 2004 年にさかのぼる. 当時, 食品の三次機能が注目され始めると, 様々な健康効 果を謳つた健康食品, サプリメントが市場に出回り 始めた。そのなかで，中国製のダイエット用健康食 品の利用による健康被害が発生し, 死亡事例も出た ことから，消費者への正しい情報提供の重要性が認 知され，HFNetが構築された。構築当初のアクセ 又数は約 5000 件/日であったが，健康食品の市場拡 大に伴い, 現在では 17000 件/日まで増えている. 


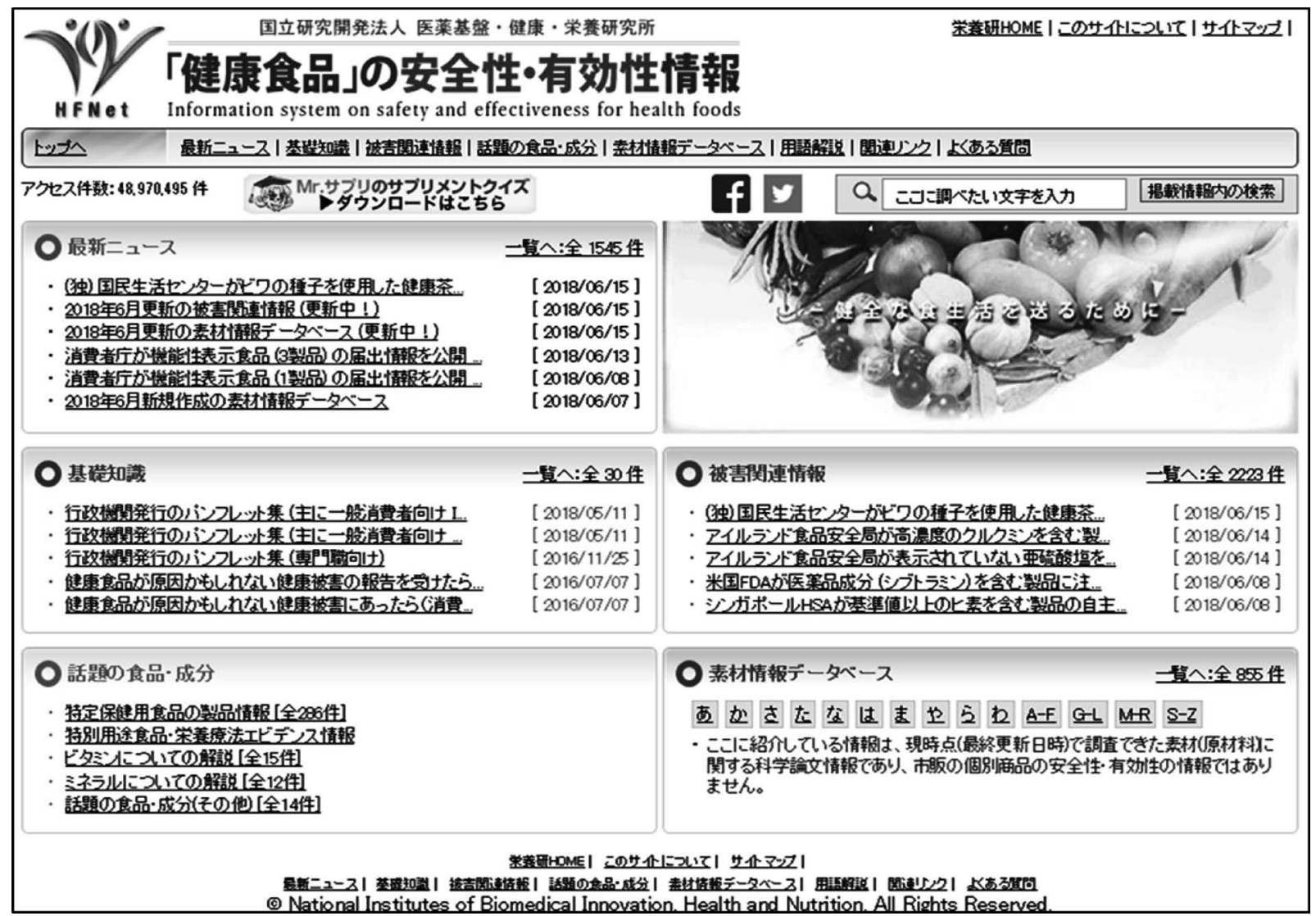

Fig. 1. Health Foods Network https://hfnet.nibiohn.go.jp/

そこで, HFNet の掲載内容について簡単に紹介す る.

\section{HFNet 掲載情報の解説}

HFNet では健康食品に関する様々な情報を扱つ ているが，基本的には消費者が適切に利用し，思わ ぬ健康被害を未然に防止するために資する情報を掲 載している。しかしながら，本サイトの内容は消費 者には若干難しいため, 薬剤師, 医師, 管理栄養 士，アドバイザリースタッフといった専門職が消費 者から相談された際に活用することを想定して構成 されている。 ただし，一般消費者の二ーズも増えて いることから，一般消費者にも分かり易い情報提供 も取り入れている.

1-1. 基礎知識本来, 健康の保持増進には普 段の食生活が重要であり，健康食品は補助的に利用 するものである。しかしながら，消費者の中には， 健康食品が主な栄養源となつている者や，病気の治 療目的に利用している者もいる.11) そこで, 消費者 が健康食品を利用する際や，医師・薬剂師が健康被 害の報告を受けた際に最低限, 知っておいてほしい
情報を掲載している. 研究所及び各行政機関により 作成された消費者向け若しくは専門職向けのパンフ レット, リーフレットの紹介もしており, すべて PDF としてダウンロードして利用できる状態にし ている. また，ビタミン・ミネラルについては，健 康食品を利用するのではなく，できる限り普段の食 事から摂取することが推奨されるため, 各種ビ夕ミ ン・ミネラルを多く含むメニューも紹介している.

1-2. 話題の食品·成分 消費者が健康食品を 利用する主な目的は栄養補給であり，そのためビタ ミン・ミネラル製品を利用している者が多い. ビタ ミン・ミネラルについては，欠乏による体調不良が 知られていることから, 食事摂取基準として, 不足 の回避を目的に推定必要量や推奨量などが示されて いる一方で，過唾摂取による健康被害を防止するた め耐容上限量が設定されているものもある。そのた め, 各ビタミン・ミネラルの役割や不足・過劋のリ スク，その他，注意点に関する解説を掲載してい る.ビタミン・ミネラル以外においても，そのとき に話題となっている成分について消費者向けの解説 
を行っている，具体的には，プエラリア・ミリフィ カ， $\alpha$-リポ酸，コエンザイム $\mathrm{Q} 10$ などを掲載して いる。.また，特定保健用食品（トクホ）の製品情報 も，各製品の有効性及び安全性試験の内容を中心に 掲載している. トクホについては，しばしば行き過 ぎた広告が見受けられるため，客観的な情報から本 当に必要かどうかを判断するために活用されること を期待する.

\section{1-3． 素材情報データベース＼cjkstart素材情報データ} ベースは本サイトの中心であり，健康食品に利用さ れている，若しくは利用される可能性のある素材に ついて，安全性及び有効性について情報を掲載して いる. 2018 年 6 月現在で 855 素材の情報を掲載し ており，ほぼ毎日，情報を追加・更新している，そ の内容については, PubMed や医中誌といつたデー タベースから論文情報を検索するだけでなく，アメ リカの Natural Medicines やドイツの Commission E Monograph などの情報も参考としている，その 中で，有効性においては，査読付きの学術論文に掲 載された，ヒトを対象とした RCT 及びメタアナリ シスを中心に掲載している，掲載に当たっては，誰 が，何を，どのくらい(量・期間) 摂取した場合に, どのような有効性が得られたかを記載し，その有効 性について拡大解釈されないように細心の注意を 払つている。一方, 安全性については，ヒトで試験 を行うことはできず，細胞，動物で行われるのが一 般的であることから，ヒトにおける情報だけでな く, 細胞, 動物試験についても幅広く掲載してい る。また近年，健康食品と医薬品との相互作用が注 目されていることから，積極的に相互作用の情報を 収集・掲載するように努めている，素材情報デー夕 ベースは，消費者が健康食品に過度の期待をせず適 切に利用できるよう，健康被害の未然防止を目的と した情報掲載に努めている。

1-4. 被害関連情報 国内外の公的機関より公 表された，健康食品が関連する健康被害や，違法製 品の取り締まり情報などを掲載している，日本国内 から発信される注意喚起情報はそれほど多くない が，海外からはほぼ毎日のように注意喚起情報が発 信されている。そのほとんどが性機能改善（シルデ ナフィル，タダラフィルなど）や瘦身効果（シブト ラミンなど）を謳い医薬品が混入された製品で，正 確には，日本では健康食品ではなく，無承認無許可
医薬品に該当する。これらの製品が日本国内で流通 する可能性は低いものの，近年はインターネットで 簡単に海外製品を個人輸入できる環境であるため, 海外製品の情報も広く掲載することで健康被害の未 然防止につなげる意図がある。また，これまでに掲 載した情報を解析することにより，今後の情報提供 のあり方について検討が可能である.

\section{2. 日本の公的機関より公表された健康被害事例}

健康食品による健康被害(体調不良)については, 様々な調査から利用者の数\%程度で起きていること が報告されている。しかしながら，そのほとんどは 軽微なものであり，因果関係も証明できない。一 方，公的機関から公表された健康被害は極めて重篤 であり，利用した製品との因果関係もはっきりして いる．HFNet の被害関連情報に掲載した情報のう ち，2010 年から 2016 年までの 6 年間に日本の公的 機関（厚生労働省及び地方自治体）より公表された 健康被害事例は 22 件あった。その中で，瘦身効果 を標榜したものは 20 件であり，被害者は若年女性 （10-30 歳代）に多く認められた（Table 1). ${ }^{2}$ 注意 喚起を出された製品のほとんどは「いわゆる健康食 品」ではなく「無承認無許可医薬品」である. しか しながら，消費者が「いわゆる健康食品」と「無承 認無許可医薬品」を判別することは難しい. また, 中には同一製品について繰り返し注意喚起が出され ている，つまり，注意喚起情報が出された後でも， これらの製品は市場に出回っているだけでなく，注 意喚起を見ていない消費者がこれらの製品を利用し て健康被害を受けているのが実態である。これらの ことから，消費者，特に若年女性に対して，積極的 に情報を発信することにより，重篤な健康被害の未 然防止につながると考えられた。

\section{3. 短大生 · 大学生における健康食品・サプリメ ントの利用実態}

若年女性で重篤な健康被害が報告されていること から，一般的な若年女性の健康食品の利用実態につ いて調査を行つた。これまで，1つの大学若しくは 数力所の大学で調查を行つた報告はいくつか見受け られるが，全国レベルで調査した報告は見当たらな い，そこで，全国の短大生・大学生を対象に健康食 品（サプリメント）の利用実態についてインター ネット調査を行った. ${ }^{3}$ 調査の結果, 短大生・大学 生の $16.8 \%$ が現在，健康食品を利用していると回 
Table 1. Adverse Event Alerts in Japan between 2010 and 2016

\begin{tabular}{|c|c|c|c|c|}
\hline & Product Name & Claim & Age & Sex \\
\hline 2010 & SUPER FAT BURNING & Weight loss & $60 \mathrm{~s}$ & $\mathrm{~F}$ \\
\hline 2010 & $\begin{array}{l}\text { FIT'X SLIM SUPER FAT } \\
\text { BURNERS }\end{array}$ & Weight loss & - & - \\
\hline 2010 & MD clinic diet & Weight loss & $10 \mathrm{~s}$ & $\mathrm{~F}$ \\
\hline 2010 & FASTIN & Weight loss & $30 \mathrm{~s}$ & M \\
\hline 2011 & MD clinic diet & Weight loss & $30 \mathrm{~s}$ & $\mathrm{~F}$ \\
\hline 2011 & Nochaka & Weight loss & $20 \mathrm{~s}$ & $\mathrm{~F}$ \\
\hline 2011 & Slimming COFFEE & Weight loss & $30 \mathrm{~s}$ & $\mathrm{~F}$ \\
\hline 2011 & Hospital diet & Weight loss & $20 \mathrm{~s}$ & $\mathrm{~F}$ \\
\hline 2012 & MD clinic diet & Weight loss & $10 \mathrm{~s}$ & $\mathrm{~F}$ \\
\hline 2012 & MD clinic diet（suspected） & Weight loss & $20 \mathrm{~s}$ & $\mathrm{~F}$ \\
\hline 2012 & MD clinic diet (suspected) & Weight loss & $10 \mathrm{~s}$ & $\mathrm{~F}$ \\
\hline 2013 & Victoria Slender & Weight loss & - & $\mathrm{F}$ \\
\hline 2013 & GLAMOROUS LINE & Weight loss & $40 \mathrm{~s}$ & $\mathrm{~F}$ \\
\hline 2013 & Victoria Slender & Weight loss & $20 \mathrm{~s}$ & $\mathrm{~F}$ \\
\hline 2013 & Miracle super style platina & Weight loss & $30 \mathrm{~s}$ & $\mathrm{~F}$ \\
\hline 2013 & Victoria Slender & Weight loss & $20 \mathrm{~s}$ & $\mathrm{~F}$ \\
\hline 2013 & OxyElite Pro & Weight loss & $20 \mathrm{~s}$ & $\mathrm{~F}$ \\
\hline 2014 & OxyElite Pro & Weight loss & $30 \mathrm{~s}$ & $\mathrm{~F}$ \\
\hline 2014 & ESTROMON & $\begin{array}{l}\text { Menopause } \\
\text { symptoms }\end{array}$ & - & $\mathrm{F}$ \\
\hline 2016 & Hospital diet & Weight loss & $20 \mathrm{~s}$ & $\mathrm{~F}$ \\
\hline 2016 & Hospital diet & Weight loss & $30 \mathrm{~s}$ & $\mathrm{~F}$ \\
\hline 2016 & Sei-tai & $\begin{array}{l}\text { Treatment of } \\
\text { disease }\end{array}$ & $50 \mathrm{~s}$ & $\mathrm{M}$ \\
\hline
\end{tabular}

答し， $15.2 \%$ が以前，利用したことがあると回答し た。つまり，短大生・大学生の約 3 割が健康食品の 利用経験者であると言える。また，学年が上がるに 従い，健康食品の利用率が高くなることも本調査か ら明らかとなった。その利用目的を聞くと，ほどん ごの学生は「栄養補給」「健康維持」と回答し，ま た製品を見ても，ビタミン・ミネラル製品の利用が 多い。その一方で，男性では「筋力の増強」目的で プロテイン・アミノ酸製品の利用が，女性では「美 容」「ダイエット」目的でダイエット関連の製品利 用が多くなっていた。 また，女性においては「プエ ラリア・ミリフィカ」の製品を利用している者も見 受けられた.プエラリア・ミリフィカの利用者にお いては，その損取が原因と思われる体調不良を経験 した者もいたため, 短大生・大学生に対しても注意 喚起が必要である。しかしながら，調査対象者にお いて，HFNet を利用している者は $1.1 \%$ に過ぎず, 見たことがないと答えた者は $84.2 \%$ にることか らも，HFNet の周知とともに，積極的な教育が必 要であると考えられた。

\section{4. 薬学部生を対象とした教育的介入}

HFNet を運用し情報提供を行っているものの， 公的機関のホームページは一般の消費者にあまり活 用されておらず，短大生・大学生においては 8 割以 上が見たこともない状況である。そこで，新たな取 り組みとして，薬学部生を対象とした教育的介入の 効果を検討した.

薬学部生を対象とした理由は，前述の短大生・大 学生を対象とした調査において，他学部 (16.7\%) に比べて医学部・薬学部 $(22.0 \%)$ の学生で健康食 品の利用率が高いためである. ${ }^{3)}$ また，薬学部の学 生の多くは将来, 薬剤師として, 患者さんにお薬だ けでなく, 健康食品の利用についても指導していく 立場となる，さらに，一部は学校薬剂師として小〜 中学生に指導していく立場となり，一部は大学講師 として次世代の大学生に教育を行う立場となること から，学生本人だけでなく，幅広い波及効果が期待 できる，そこで，講義前後のアンケート回答を比較 することにより教育介入による意識の変化を調べ た．実際の調査は次のような手順で行った，1）健 康食品への認識についてアンケートを行う，2）健 康食品の品質や健康被害事例，医薬品との相互作用 などに関する講義（約 1 時間），3）講義終了直後に 1）と同一のアンケートを行う。その結果，講義介 入により健康食品に対する意識が適切な方向へ変化 しており，講義による教育介入の効果が明らかと なった．今後はこの意識の変化が持続するのか，ま た薬剤師として現場に出た際に，役に立つのかな ど，長期的な視点に立つて検討を行っていく予定で ある。

\section{5. サプリメントと医薬品の併用実態}

健康食品のなかでも一般的にサプリメント（錠 凨，カプセル，粉末状の製品）と称されるものは, 特定の成分が濃縮されていることから，医薬品との 相互作用の懸念がある。医薬品との相互作用は，医 薬品の作用を減弱若しくは増強させ，治療効果に影 響するだけでなく，場合によっては副作用を増強す ることにより健康被害をもたらす可能性がある。そ こで，サプリメント（錠剤，カプセル，粉末状の製 品に限定）と医薬品との併用実態についてインター ネット調查を行った. ${ }^{4)}$ 調査の結果, サプリメント 利用者の $19.8 \%$ がサプリメントと医薬品を併用し ており，多くの者が複数のサプリメントと複数の医 
薬品を併用している実態を明らかにした，さらに， 通院中の者の約 7 割, 受診していない者の約 8 割が 医師・薬剂師にサプリメントの利用を相談していな かった。 医師・薬剤師に相談しない理由として, 「食品だから」治療中の病気と関係ない製品だから」 といった回答が多かったが，中には「医師・薬剤師 に聞かれなかったから」という回答もあり, 患者さ んの健康食品・サプリメントの利用について医師・ 薬剂師が積極的に聞く必要があることが明らかと なった.

6. まとめ

健康食品の利用による健康被害の未然防止のため,

HFNet を介して情報提供を行うとともに，積極的 な教育が有効であることが示唆された。健康食品の 利用は病者においても増えており，中には病気の治 療目的とした利用も見受けられることから，患者さ んの健康食品の利用においては薬剤師の役割が重要 となってくる. もちろん, 健康食品の中には患者さ んの体調管理に役立つものもあるだけでなく，その 利用は，患者さんが病気を早く治したいという気持 ちの表れでもあることから，一概に利用を否定する のではなく, 患者さんと相談しながら適切に利用し
てもらうことが重要である，その際には，是非， HFNet を参考情報として活用して頂きたいと思う.

\section{謝辞本研究は厚生労働行政推進調査事業費} （H27-食品-指定-014）により実施したものである. 大学生への教育介入研究にご協力頂きました帝京大 学薬学部 黄倉 崇教授, 岩手医科大学薬学部 弘瀬 雅教教授, 斉藤麻希助教, 麻布大学生命 - 環境科学 部 関本征史准教授, 武庫川女子大学薬学部 水野英 哉准教授に深く感謝いたします。

利益相反開示すべき利益相反はない.

\section{REFERENCES}

1) Chiba T., Sato Y., Nakanishi T., Yokotani K., Suzuki S., Umegaki K., Nutrients, 6, 53925404 (2014).

2) Kobayashi E., Sato Y., Umegaki K., Chiba T., Shokuhin Eiseigaku Zasshi, 59, 93-98 (2018) .

3) Kobayashi E., Sato Y., Umegaki K., Chiba T., Nutrients, 9, 1250 (2017).

4) Chiba T., Sato Y., Suzuki S., Umegaki K., Nutrients, 7, 2947-2960 (2015). 